cardiovascular death: early results of a prospective study. Lancet 1980; $1050-4$.

4 Wilhelmsen L, Svardsudd K, Korsan-Bengstan K, et al. Fibrinogen as a risk factor for stroke and myocardial infarction. $N$ Engl f Med 1984;311:501-5. Stone MC, Thorpe JM. Plasma fibrinogen - a major coronary risk factor. I R Coll Gen Pract 1985;35:565-9.

6 Meade TW, Brozovic M, Chakrabarti R, et al. Haemostatic function and ischaemic heart disease: principal results of the Northwick Park heart study. Lancet 1986;ii:533-7.

7 Lewis HD Jr, Davis JW, Archibald DG, et al. Protective effects of aspirin against acute myocardial infarction and death in men with unstable angina. Results of a Veterans Administration cooperative study. $N$ Engl f Med 1983;309:396-403.

8 Cairns JA, Gent $M$, Singer J. Aspirin, sulfinpyrazone, or both in unstable angina. Results of a Canadian multicenter trial. $N$ Engl $\mathcal{F}$ Med 1985;313: 1369-75.

9 Elwood PC, Cochrane AL, Burr ML, et al. A randomised controlled trial of acetylsalicylic acid in the secondary prevention of mortality from myocardial infarction. Br Med f 1974;i:436-40.

10 Coronary Drug Project Research Group. Aspirin in coronary heart disease. f Chronic Dis 1976;29:625-42.

11 Breddin K, Loew D, Lechner K, Uberla K, Walter E. Secondary prevention of myocardial infarction: comparison of acetylsalicylic acid, phenprocoumon and placebo: a multicenter two-year prospective study. Thromb Haemost 1979:4:225-36:

12 Elwood PC, Sweetham PM. Aspirin and secondary mortality after myocardial infarction. Lancet 1979;ii:1313-5.

13 Aspirin Myocardial Infarction Study Research Group. A randomized, controlled trial of aspirin in persons recovered from myocardial infarction. TAMA 1980;243:661-9.

14 Persantin-Aspirin Reinfarction Study Research Group. Persantin and aspirin in coronary heart disease. Circulation 1980;62:449-61.

5 Patrono C. Aspirin for the prevention of coronary thrombosis: current facts and perspectives. Eur Heart $\mathcal{f}$ 1986; 7:454-9.

16 Steering Committee of the Physicians' Health Study Research Group. Preliminary report: findings from the aspirin component of ongoing physicians' health study. $N$ Engl f Med 1988;318:262-4.

17 Peto R, Gray R, Collins R. Randomised trial of prophylactic daily aspirin in British male doctors. Br Med f 1988;296:313-6.

18 Antiplatelet Trialists' Collaboration. Secondary prevention of vascular disease by prolonged antiplatelet treatment. BrMed f 1988;296:320-32.

19 UK-TIA Study Group. United Kingdom transient ischaemic attack (UK-TIA) aspirin trial: interim results. $\mathrm{Br}$ Med f 1988;296:316-20.

20 ISIS-2 Collaborative Group. Randomised trial of intravenous streptokinase, oral aspirin, both, or neither among 17,187 cases of suspected acute myocardial infarction. Lancet 1988;ii:349-60.

21 Patrono C, Ciabattoni G, Badrignani $P$, et al. Clinical pharmacology of platelet cyclo-oxygenase inhibition. Circulation 1985;72:1177-84.

22 Hanley SP, Bevan J, Cockbill SR, Heptinstall S. Differential inhibition by low dose aspirin of human prostacyclin synthesis and platelet thromboxane synthesis. Lancet 1981;i:969-71.

23 Pedersen AK, Fitzgerald GA. Dose related kinetics of aspirin. Pre-systemic acetylation of platelet cyclooxygenase. $N$ Engl F Med 1984;311:1206-11

24 Sixty Plus Reinfarction Study Group. Collaborative analysis of long-term anticoagulant therapy in elderly patients after myocardial infarction. Lancel $1980 ; \mathrm{i}: 203-9$.

25 Petitti DB, Strom BL, Melmon KL. Duration of warfarin anticoagulan therapy and the probabilities of recurrent thromboembolism and hemorrhage. Am J Med 1986;81:255-9.

26 Meade TW, Wilkes HC, Stirling Y, Brennan PJ, Kelleher C, Browne W. Randomised controlled trial of low dose warfarin in the primary prevention of ischaemic heart disease in men at high risk: design and pilot study. Eur Heart $f$ 1988;9:836-43.

27 Hawkey CJ, Simpson G, Somerville KW. Reduction by enprostil of aspirin nduced blood loss from human gastric mucosa. Am $\mathcal{Y}$ Med 1986;81(2A) $50-4$.

28 Fisher MA, Hunt JN. A sensitive method for measuring haemoglobin in gastric contents. Digestion 1976;14:409-19.

29 Machin D, Campbell MJ. Statistical tables for the design of clinical trials. Oxford: Blackwell Scientific Publications, 1987:86-8.

30 Graham DY, Smith JL. Aspirin and the stomach. Ann Intern Med 1986;104: 390-8.

31 Graham DY, Smith JL, Spjut HJ, Torres E. Gastric adaptation studies in humans during continuous aspirin administration. Gastroenterology 1988:95: 327-33.

32 Shorrock CJ, Rees DW. Effect of indomethacin on human gastroduodenal "mucus-bicarbonate" barrier. Gut 1987;28:A1411.

33 Pierson RN, Holt PR, Watson RM, Keating KP. Aspirin and gastrointestinal bleeding. 51 Chromate blood loss studies. Am f Med 1961;31:259-65.

34 Johnson PC. Gastrointestinal consequences of treatment with drugs in elderly patients. Am Geriatr Soc 1982;30(suppl):52-7

35 Somerville KW, Faulkner G, Langman MJSL. Non-steroidal antiinflammatory drugs and bleeding gastric ulcer. Lancet 1986;i:462-4.

36 Hawkey CJ, Somerville KW, Marshall S. Prophylaxis of aspirin induced gastric mucosal bleeding with ranitidine. Alimentary Pharmacological Therapy 1988;2:245-52.

37 Prichard PJ, Kitchingman GK, Hawkey CJ. Gastric mucosal bleeding: what dose of aspirin is safe? Gut 1987;28:A 1401.

38 Coggon D, Langman MJS, Spiegelhalter D. Aspirin, paracetamol, and haematemasis and melaena. Gut 1982;23:340-4.

39 Somerville KW, Prichard PJ, Faulkner G, Langman MJS. Aspirin and bleeding peptic ulcer. Gastroenterology 1987;92:1649.

40 Stuart MJ, Gross SJ, Elrad H, Graeber JE. Effects of acetylsalicylic acid ingestion on maternal and neonatal hemostasis. N Engl f Med 1982;307

(Accepted 2 December 1988)
Department of

Endocrinology, Charing

Cross Hospital, London, and Department of Medicine and Blood

Pressure Unit, Charing

Cross and Westminster

Medical School, London

W6 8RF

R J C Guy, MD, senior

registrar

Y Turberg, MD, senior house officer

R N Davidson, MD, senior

registrar

G Finnerty, MRCP, registrar

G A MacGregor, FRCP,

Wellcome senior lecturer

P H Wise, FRCP, consultant

endocrinologist

Correspondence to:

Dr Wise.

BrMed f 1989;298:496-7

\section{Mineralocorticoid deficiency in HIV infection}

\author{
R J C Guy, Y Turberg, R N Davidson, \\ G Finnerty, G A MacGregor, P H Wise
}

Infection with the human immunodeficiency virus (HIV) may result in adrenal necrosis and hence a deficiency of cortisol..$^{1-3}$ We report on a patient who developed severe sodium and water depletion because of a deficiency in production predominantly of mineralocorticoids. This important, easily treatable complication has probably been overlooked in patients infected with HIV.

\section{Case report}

A homosexual man aged 41 was admitted in April 1988 with a diagnosis of pneumocystis pneumonia. He was positive for HIV antibody. On admission his serum sodium concentration was $129 \mathrm{mmol} / \mathrm{l}$, potassium $4.7 \mathrm{mmol} / 1$, and urea $5.1 \mathrm{mmol} / \mathrm{l}$. Treatment with high doses of co-trimoxazole was started. His symptoms improved, and he was discharged 11 days later. His serum sodium concentration, however, had fallen during his admission and at discharge was $114 \mathrm{mmol} / \mathrm{l}$; serum potassium and urea concentrations were $5 \cdot 8$ $\mathrm{mmol} / \mathrm{l}$ and $9.7 \mathrm{mmol} / \mathrm{l}$, respectively. His serum cortisol concentration was measured, but the result was not available at discharge.

He was readmitted the next day complaining of feeling faint on walking, leg weakness, and breathlessness. Examination showed profound postural hypotension (blood pressure lying $120 / 80 \mathrm{~mm} \mathrm{Hg}$, un- recordable on standing); hyponatraemia (sodium concentration $110 \mathrm{mmol} / \mathrm{l}$ ) and hyperkalaemia (potassium concentration $6.7 \mathrm{mmol} / \mathrm{l}$ ) were more pronounced. Treatment with intravenous physiological saline relieved the symptoms, and Addison's disease was diagnosed provisionally. At this stage, however, the serum cortisol concentration in the sample obtained during the first admission was found to be $992 \mathrm{nmol} / \mathrm{l}$ (normal $250-550 \mathrm{nmol} / \mathrm{l}$ ). He was given oral dexamethasone $(0.5 \mathrm{mg}$ twice daily) and sustained release sodium $600 \mathrm{mg}$ three times daily, and an intravenous tetracosactrin test was performed (table). Plasma renin activity (after 10 minutes' sitting) was appreciably raised at $55 \mathrm{nmol} / \mathrm{l} / \mathrm{h}$ (normal $0.4-1.9 \mathrm{nmol} / \mathrm{l} / \mathrm{h}$ ), and plasma aldosterone concentration was $149 \mathrm{pmol} / \mathrm{l}$, which was low considering his high plasma renin activity. His 24 hour urinary excretion of sodium was $240 \mathrm{mmol}$. Treatment was changed to hydrocortisone $20 \mathrm{mg}$ in the morning and $10 \mathrm{mg}$ at night with fludrocortisone $0.1 \mathrm{mg}$ daily, which was increased to $0.2 \mathrm{mg}$ daily. Within 10 days this had corrected his postural hypotension (blood pressure lying $110 / 70 \mathrm{~mm}$ $\mathrm{Hg}$, standing $130 / 80 \mathrm{~mm} \mathrm{Hg}$ ) and restored his serum electrolyte concentrations to normal (sodium 136 $\mathrm{mmol} / \mathrm{l}$, potassium $3.6 \mathrm{mmol} / \mathrm{l}$, and urea $3.3 \mathrm{mmol} / \mathrm{l}$ ). Plasma renin activity fell to $5.8 \mathrm{nmol} / \mathrm{l} / \mathrm{h}$ and plasma aldosterone concentration remained low at $59 \mathrm{pmol} / \mathrm{l}$. $\mathrm{He}$ was negative for autoantibodies, and computed tomography of his adrenal glands showed a normal size and structure.

\section{Comment}

The patient's high plasma renin activity and low plasma aldosterone concentration with profound hyponatraemia indicated a severe mineralocorticoid 
Results of intravenous tetracosactrin test $(500 \mathrm{mg}$ in $500 \% 5 \%$ dextrose) performed when patient was taking dexamethasone $0.5 \mathrm{mg}$ twice daily

\begin{tabular}{lc}
\hline $\begin{array}{l}\text { Time } \\
\text { (hours) }\end{array}$ & $\begin{array}{c}\text { Plasma cortisol } \\
\text { concentration } \\
(\text { nmol/l) }\end{array}$ \\
\hline 0 & 75 \\
1 & 346 \\
2 & 412 \\
3 & 421 \\
4 & 470 \\
5 & 479 \\
\hline
\end{tabular}

${ }^{\star}$ Expected maximum $>600 \mathrm{nmol} / \mathrm{l}$. deficiency. The high cortisol concentration during his first admission suggested that there was no deficiency in production of glucocorticoids, only in mineralocorticoids, although the suboptimal rise during infusion of tetracosactrin indicated some loss of reserve cortisol.

Postmortem studies have shown a high prevalence of adrenal disease in patients with AIDS. In one study of 41 subjects at necropsy $51 \%$ had cytomegalovirus adrenalitis. Hyponatraemia was the most common finding (in $75 \%$ ), although only two subjects had been suspected during life of having adrenal insufficiency. ${ }^{1}$ Stimulation with tetracosactrin may indicate impairment of adrenal function despite normal or high cortisol concentrations measured at random. ${ }^{1-3}$

The cause of the adrenal dysfunction in our case is unknown; the dysfunction would probably have been overlooked if reliance had been placed on the raised cortisol concentration. We suggest that in patients with AIDS with lethargy, hypotension, hyponatraemia, or hyperkalaemia, deficiencies of mineralocorticoids and glucocorticoids should be investigated by measurement of aldosterone concentration and plasma renin activity; prolonged stimulation with tetracosactrin (intravenously or intramuscularly); and, perhaps, assay of serum adrenocorticotrophic hormone concentration when the serum cortisol concentration is normal or low.

Our findings suggest that some of the morbidity associated with AIDS is a result of mineralocortical deficiency. Adrenal complications caused by HIV are easily treated and should be considered in all patients with infections related to AIDS.

We thank Dr Louise Sugden for measuring plasma renin activity; Mrs Michelle Miller for measuring plasma aldosterone concentration; and Professor A Guz for permission to report this case.

1 Glasgow BJ, Steinsapir KD, Anders K, Layfield LJ. Adrenal pathology in the acquired immune deficiency syndrome. Am f Clin Pathol 1985;84:594-7.

2 Membreno L, Irony I, Dere W, Klein R, Biglieri EG, Cobb E. Adrenocortical function in acquired immunodeficiency syndrome. $\mathcal{F}$ Clin Endocrinol Metab 1987;65:482-7.

3 Greene LW, Cole W, Greene JB, et al. Adrenal insufficiency as a complication of the acquired immunodeficiency syndrome. Ann Intern Med 1984;101:497-8.

(Accepted 14 November 1988)

\section{Assessing glycaemic control in non-insulin dependent diabetes: acceptability of blood sampling at home}

\author{
Alice Tippetts, PaulCallaway, Brian Leatherdale, \\ David Rowe
}

Department of Diabetes and Endocrinology, Royal South Hants Hospital, Southampton SO9 4PE Alice Tippetts, medical student

Paul Callaway, MRCP, research registrar

Brian Leatherdale, FRCP, consultant physician

\section{Department of Chemical Pathology, Southampton General Hospital, Southampton \\ David Rowe, MRCPATH, top grade biochemist}

Correspondence to: Dr Callaway.

BrMed f 1989;298:497-8
Measurement of glycosylated haemoglobin concentration is an accurate and convenient method of assessing overall glycaemic control in diabetes but is expensive and labour intensive.' In non-insulin dependent diabetes fasting blood glucose concentration correlates well with glycosylated haemoglobin concentration and is much cheaper to measure. ${ }^{2}$ In our hospital patients are therefore asked to have their fasting blood glucose concentration estimated before their visit to the clinic. This requires patients to make a visit to the laboratory while fasting.

We studied the acceptability and relative costs of three methods of obtaining samples for measuring fasting glucose concentration: by venepuncture in the laboratory and by finger pricking at home to produce blood spots on filter paper and reagent strips (BM 1-44; Boehringer Mannheim). Blood spots on filter paper have been used in previous studies, ${ }^{34}$ but their acceptability to patients is not known.

\section{Patients, methods, and results}

Sixty eight non-insulin dependent diabetics who did not regularly monitor their blood glucose concentrations at home agreed to produce blood spots and use reagent strips at home after fasting. All received oral and written instructions on performing the tests from one investigator. Samples were enclosed in plastic bags and returned in envelopes to the laboratory.

We analysed blood spots, which are stable at room temperature for eight days, by the method described by Gamlen et al.5 The results correlated well with venous blood glucose concentrations measured with a Yellow Springs analyser $(r=0.977 ; \mathrm{p}<0.001 ; n=56)$. Values obtained with reagent strips read with a reflectance meter at the time of sampling $(r=0.909$; $\mathrm{p}<0.001 ; \mathrm{n}=45$ ) and after postal delivery to the clinic $(\mathrm{r}=0.900 ; \mathrm{p}<0.001 ; \mathrm{n}=45)$ also correlated well with venous concentrations.

Fifty patients returned both "blood tests, and one patient returned only the blood spot. There were no significant differences in age, sex, or duration of diabetes between respondents and non-respondents. Four of the 10 patients who had used reagent strips before produced inadequate strips (Fisher's exact test $\mathrm{p}=0.043$ ), although all produced adequate blood spots. Patients with no experience of finger pricking produced significantly better spots than strips (table).

Adequacy of reagent strips and blood spots on filter paper produced by 40 patients with no experience of finger pricking $\star$

\begin{tabular}{lccc}
\hline & \multicolumn{3}{c}{ Spots } \\
\cline { 2 - 4 } Reagent strips & Adequate & Inadequate & Total \\
\hline Adequate & 14 & 8 & 14 \\
Inadequate & 18 & 8 & 40
\end{tabular}

McNemar's test statistic (with Yates's correction) $=\mathbf{1 6} \cdot \mathbf{0 5}, \mathrm{p}<\mathbf{0} \cdot 0005$

*Reagent strips were considered inadequate if blood was smeared or did not * Reagent strips were considered inadequate if blood was smeared or did not cover the whole colour block, or if they could not be read by a reflectance
meter. Filter paper spots were considered inadequate if blood had not meter. Filter paper spots were considered inadequate
soaked through the filter paper to a diameter of $6 \mathrm{~mm}$.

Patients who produced adequate strips were on average younger (mean (SD) age $57 \cdot 4(14 \cdot 1)$ years) than those who produced inadequate strips $(65 \cdot 6(9 \cdot 2))$ $(\mathrm{p}=0.033)$. This was also true for spots $(61.3(12 \cdot 4) v$ $67 \cdot 3(7 \cdot 2)$ years, $p=0 \cdot 033)$.

Fifty one patients, 47 of whom had returned samples, later returned a questionnaire. Eighteen found visits for laboratory sampling inconvenient. Of the 45 who stated preferences, 31 preferred home sampling to venepuncture at the laboratory or the general practitioner's surgery. Preference was not significantly related to age, sex, or duration of diabetes.

With information from the questionnaire and the laboratory we estimated costs of materials and technicians' time and costs to patients of the three methods of sampling; blood spots had to be posted to the laboratory, whereas patients took reagent strips to the clinic to be read by a reflectance meter. Sampling at the hospital was most expensive for both the NHS 